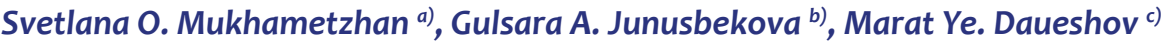

a, b) Academy of Public Administration under the President of the Republic of Kazakhstan, Nur-Sultan, Kazakhstan

c) Agency of the Republic of Kazakhstan for Civil Service Affairs, Nur-Sultan, Kazakhstan

a) https://orcid.org/0000-0003-0437-5048

b) http://orcid.org/0000-0002-2709-652X, e-mail: gulsara.dzhunusbekova@apa.kz

\title{
The Management of Urban Development for the Regional Economic Growth: the Example of Kazakhstan'
}

Considering the increasing imbalance in the economic development of urbanised territories of Kazakhstan, examining the impact of urbanisation on the economic growth of cities to ensure their innovative development is necessary. This study analyses trends and problems of the impact of urbanisation on urban development on the example of Kazakhstan. The article focuses on urban development and related processes that will open new opportunities for Kazakhstan to accelerate economic growth and improve living standards. The works of local researchers do not show the relationship between the levels of urban and economic development in different regions of the country and the impact of urbanisation on this process. To supplement previous studies, we used statistical and comparative analysis methods. Moreover, we compared the current state of urban development in Kazakhstan with the situation in other countries. The obtained empirical estimates confirm the correlation between the level of urbanisation of a country and its economic growth. Without a holistic approach to urban management, it is difficult to establish the directions, principles and development strategies for Kazakhstan's cities and megacities to follow. Thus, we identified the main directions for economic growth of urbanised territories of Kazakhstan: proper control and management of urbanisation, flexible management, development of appropriate policies for different regions of the country, use of best practices in developing urban strategies. We recommend considering the analysis of urban management in the broader context, and not only as a task of implementing regional economic growth. For that purpose, it is necessary to create an integrated multi-level management system that provides feedback and preventive management, classifying the consequences of urban policy in the regions and the effects of achieving the country's strategic development goals. Therefore, the Kazakh government should at least review its functions and responsibilities and look for solutions to achieve a tangible synergistic effect.

Keywords: urbanisation, urban areas, urban planning, economic development, regional policy, urban development, economic growth, urban management, metropolitan areas, urban agglomeration, Kazakhstan, Kazakh development strategy

For citation: Mukhametzhan, S. O., Junusbekova, G. A. \& Daueshov, M. Ye. (2020). Urban Development Management in Pursuit of Regional Economic Growth: the Example of Kazakhstan. Ekonomika regiona [Economy of region], 16(4), 12851301, https://doi.org/10.17059/ekon.reg.2020-4-19

\footnotetext{
1 () Mukhametzhan S. O., Junusbekova G. A., Daueshov M. Ye. Text. 2020.
} 
ОРИГИНАЛЬНАЯ СТАТЬЯ

C. О. Мухаметжан ${ }^{a)}$, Г. А. Джунусбекова ${ }^{\text {б) }}$, M. Е. Дауешов ${ }^{\text {) }}$

а, 6) Академия государственного управления при Президенте Республики Казахстан, Нур-Султан, Казахстан

в) Агентство Республики Казахстан по делам государственной службы, Нур-Султан, Казахстан

a-https://orcid.org/0000-0003-0437-5048

6) http://orcid.org/0000-0002-2709-652X, e-mail: gulsara.dzhunusbekova@apa.kz

\title{
Влияние управления развитием городов на экономический рост региона: на примере Казахстана
}

\begin{abstract}
Учитывая усиливающийся дисбаланс в экономическом развитии городских территорий Казахстана, мы считаем иелесообразным изучить влияние урбанизации на экономический рост городов и обеспечение их инновационного развития. Данное исследование анализирует тенденции и проблемы влияния урбанизации на развитие городов в Казахстане. Первостепенное внимание уделяется развитию современных городов и связанным с ним процессам, открывающим новые перспективы ускорения экономического роста и повышения уровня жизни в Казахстане. В работах отечественных исследователей взаимосвязь между городским и экономическим развитием и влиянием урбанизации на этот процесс в разных регионах страны не выявлена. Для восполнения пробела в предыдущих исследованиях мы использовали методы статистического и сравнительного анализа. Проведено сравнение уровня городского развития в Казахстане и в других странах. Полученные эмпирические данные подтверждают существование взаимосвязи между уровнем урбанизации и экономическим ростом в стране. Очевидно, что без комплексного подхода куправлению городами сложно сбормулировать направления, приниипы и стратегии развития городов и мегаполисов Казахстана. Определены основные направления экономического роста городских территорий Казахстана: контроль за процессами урбанизации, гибкое управление, разработка соответствующей политики (в зависимости от особенностей разных регионов страны), использование передовых практик создания городских стратегий. Управление городскими территориями следует рассматривать не только в качестве средства достижения экономического роста региона, но и в более широком контексте. Для этого необходимо создать интегрированную многоуровневую систему управления, которая обеспечивает обратную связь и превентивное управление, систематизируя результаты проведения муниципальной политики в регионах и достижение стратегических целей развития страны. Таким образом, правительству Казахстана необходимо пересмотреть свои функции и обязанности, скониентрировавшись на поиске решений для достижения ошутимого синергетического эфбекта.

Ключевые слова: урбанизация, городские территории, городское планирование, экономическое развитие, региональная политика, градостроительство, экономический рост, управление городами, мегаполисы, городские агломерации, Казахстан, стратегия развития Казахстана
\end{abstract}

Для цитирования: Мухаметжанова С. О., Джунусбекова Г. А., Дауешов М. Е. Управление развитием городов для экономического роста региона: на примере Казахстана // Экономика региона. 2020. Т. 16, вып. 4. С. $1285-1301$. https://doi.org/10.17059/ekon.reg.2020-4-19

\section{Introduction}

Urbanisation is one of the pillars of the Strategy for development of the Republic of Kazakhstan until the year 2050 (the Kazakhstan-2050 Strategy $)^{1}$. Urbanisation reflects the social development and indicates the country's position in the global economy since cities have long been the centres of human, financial, technical, information and organisational resources. They are a driving force for economic development because, in recent decades, urbanisation has become especially important for not only economic growth and job creation, but for social development. The United Nations (UN) recently reported that more than half of the world's population currently lives in cities, and it is predicted that by 2050 , this figure will increase by two thirds. Thus,

\footnotetext{
${ }^{1}$ Official site of the President of the Republic of Kazakhstan (2019). Retrieved from: http://www.akorda.kz/ru/official_documents/strategies_and_programs (Date of access: 10.10.2019).
}

there is an urgent need to make urban planning and public services more sustainable. According to the UN Department of Economic and Social Affairs (DESA), changes in demographics, as well as population growth across the world, could lead to another 2.5 billion people moving to cities by 2050. Meanwhile, the number of megacities (cities with a population of more than 10 million) will also increase significantly by 2030 , meaning that $70 \%$ of global gross domestic product (GDP) will be generated in megacities ${ }^{2}$. As in most countries worldwide, the processes of urbanisation in Kazakhstan are gradually intensifying. Global interest in the features, models, factors and principles of urban development is growing for many reasons: the increase in population mobility, the creation of a post-industrial

\footnotetext{
${ }^{2}$ United Nations (2018). World Urbanization Prospects: The 2018 Revision. Retrieved from: https://population.un.org/wup/ Publications/ (Date of access: 10.10.2019).
} 


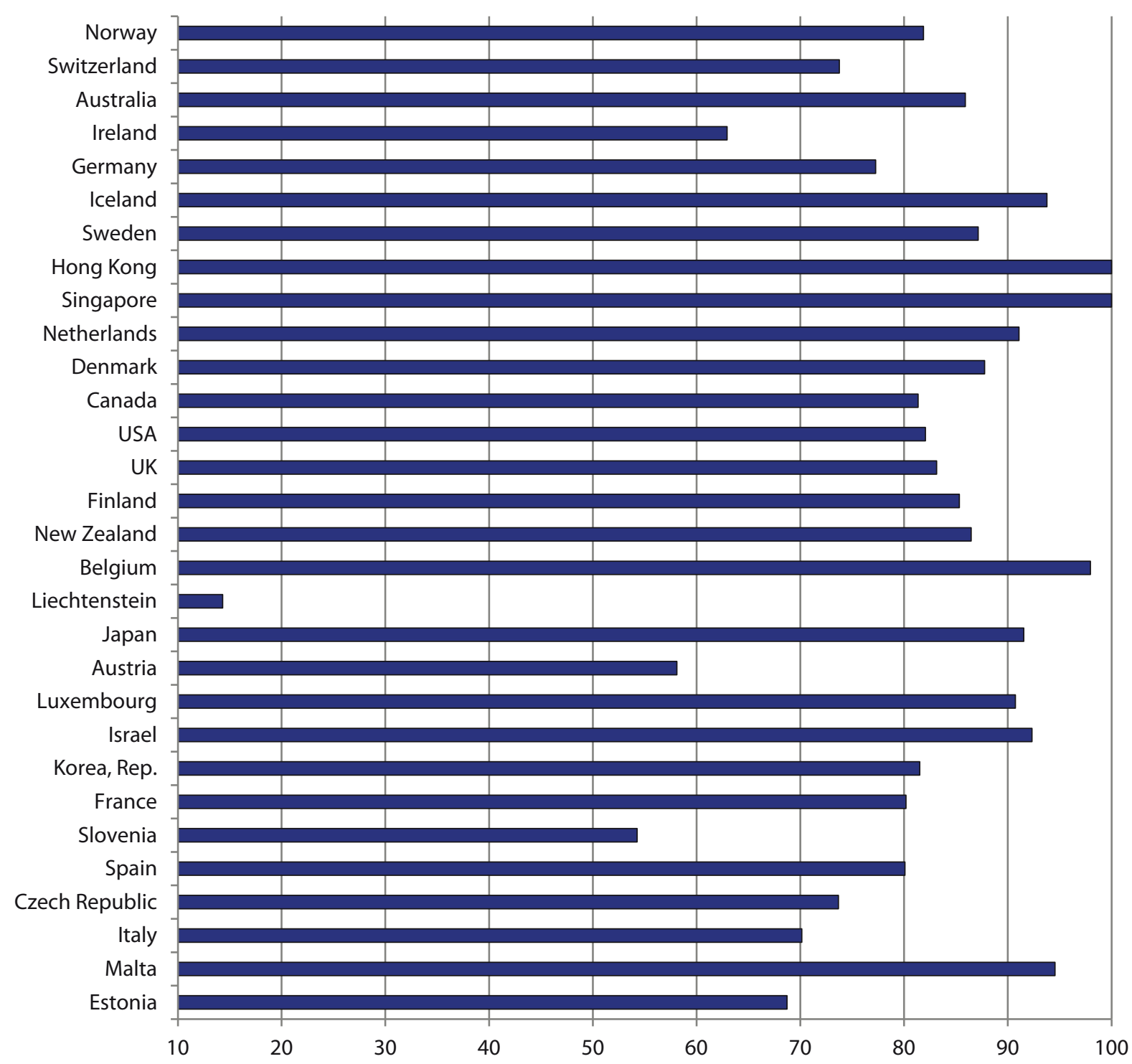

Fig. 1. Level of urbanisation of top 30 countries in the Human Development Index (2017), \%

1) Source: compiled according to the UN (UNDP, Human Development Report. Retrieved from: http://hdr.undp.org/en/2018-upDate (Date of access: 10.10.2019)).

2) Source: compiled according to the World Bank (World Bank Statistical Resources. Retrieved from: https://data.worldbank.org/indicator/SP.POP.TOTL?locations=KZ (Date of access: 10.10.2019)).

economy (the introduction of new standards to improve SMART), and the growing concentration of people in cities. The largest cities and their agglomerations are also characterised by a change in urban functions, indicating the strengthening of post-industrial sectors, a change in urban lifestyle and quality of life, as well as the complexity of city management processes. These factors lead to the need for an in-depth study of economic resources of urbanisation. Agglomerations are especially in demand in Kazakhstan with its large territory and vast distances. They can organise economic and social life in large spaces around them, increase the investment attractiveness of territories (centres of production and innovative technologies), increase the capacity of re- gional markets, and support elements of the spatial development of the country. Additionally, agglomerations may even become a mechanism for equalising territorial development.

Urban development refers to the processes of increasing the role of cities in the development of society [1]. The Human Development Index (HDI) is based on the calculation of three indicators: gross national income per capita at purchasing power parity, life expectancy and the duration of education in educational institutions. The HDI demonstrates the relationship between human capital development and the level of urbanisation, where two thirds of 30 leading countries have an urbanisation rate above $75 \%$ (Figure 1). Simultaneously, Kazakhstan ranks 58th. 


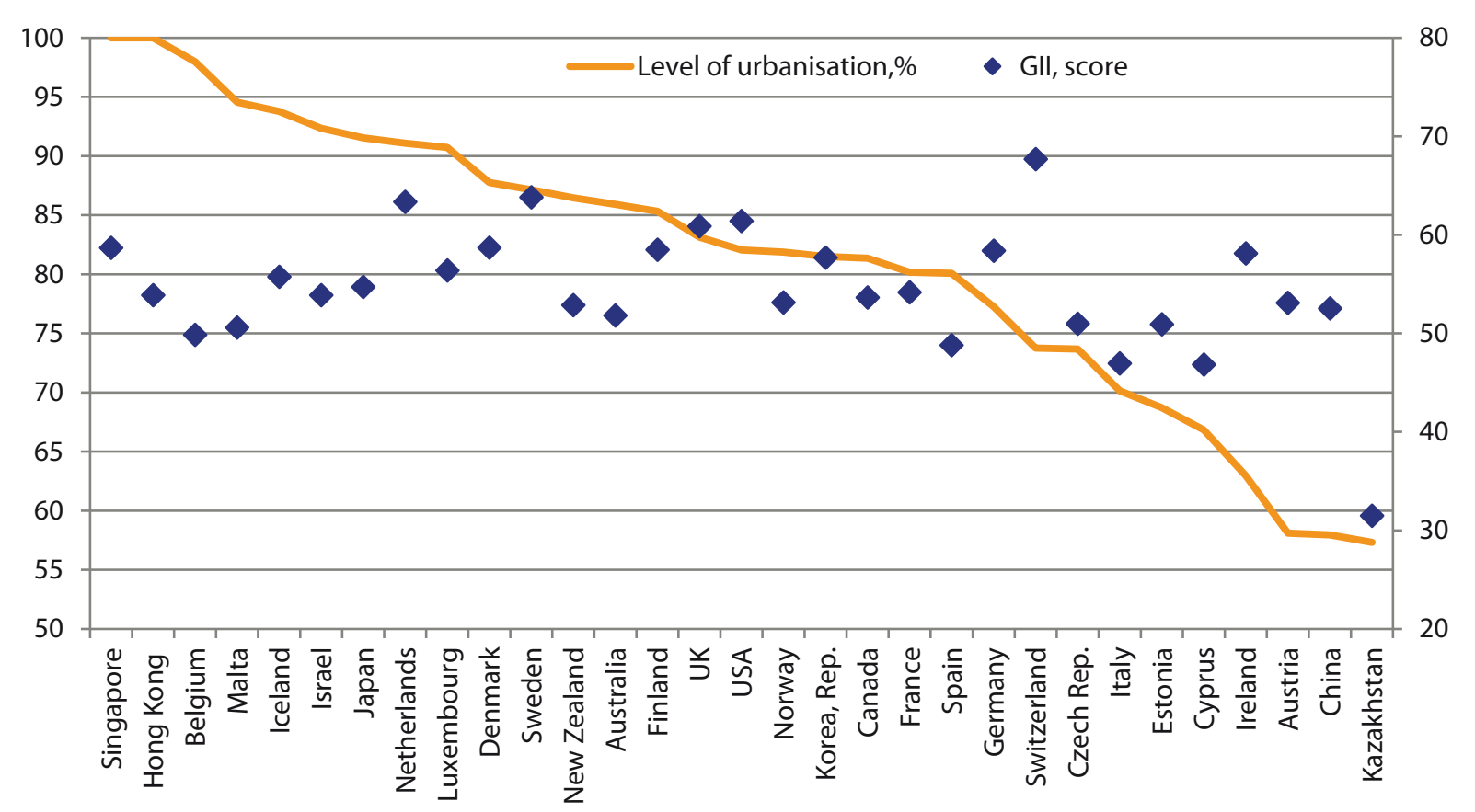

Fig. 2. Top 30 urban countries in the Global Innovation Index (GII) and their level of urbanisation (2017) (score, \%) 1) Source: compiled according to the Global Innovation Index. Analysis. Explore the interactive database of the Gll: The 2017 Revision. Retrieved from: https://www.globalinnovationindex.org/analysis-indicator/ (Date of access: 10.10.2019)).

2) Source: compiled according to the World Bank (World Bank Statistical Resources). Retrieved from: https://data.worldbank.org/ indicator/SP.POP.TOTL?locations=KZ (Date of access: 10.10.2019).

3) Source: compiled according to the World Bank (World Bank Statistical Resources). Retrieved from: https://data.worldbank.org/ indicator/SP.URB.TOTL.IN.ZS (Date of access: 10.10.2019).

Thus, the level of urbanisation can affect social development, as well as the quality of human and social capital.

The socio-economic progress of cities can help solve some problems using various development tools. The urban environment contributes to the effective management of cities, accelerating innovation processes and creating new opportunities for implementing and disseminating existing innovations [2, p. 30]. Ultimately, it positively contributes to economic development, living conditions and the environment. Undoubtedly, many cities today want to promote innovation activities that accelerate their economic development. The opportunities for the simultaneous use of financial and managerial know-how as well as highly qualified personnel determine the attractiveness of a city for innovation.

Given the appropriate conditions, cities can stimulate ideas, provide knowledge-sharing at the local level and promote innovation to accelerate economic growth [3]. In this regard, it is advisable to jointly consider the innovative development of cities and the processes of urbanisation (Figure 2).

The Global Innovation Index (GII) is a global study and an accompanying ranking of the countries of the world in terms of innovative development.
According to the above data, top 30 countries in terms of innovative development also have a high level of urbanisation. However, Kazakhstan occupies only 74 th place.

Thus, even modern states cannot ignore the ongoing changes and avoid the processes of urbanisation. Moreover, states are obliged to manage these changes to ensure the greatest benefit for society.

To achieve the goals set in the Kazakhstan-2050 strategy, it is necessary to focus on the qualitative aspects of urbanisation. Following the New City Programme and the UN Sustainable Development Goals, Kazakhstan can turn its cities into the engines of economic and social development. To ensure the well-being of citizens, it is necessary to find the right answers to the most important problems of urbanisation, such as housing, utilities, land use, urban transport and internal migration. The existing urban management system lacks necessary tools and incentives to ensure sustainable and socially oriented urban development.

On the one hand, the example of Kazakhstan illustrates the rapid development of urban areas, employment growth, diverse economic activities and the concentration of large companies in urban areas. On the other hand, there is a decline in small and medium-sized cities of Kazakhstan, which neither have realised their potential nor 
have become a driving force for socio-economic development.

The article argues that for a better understanding of the relationship between economic growth and urban development, it is important to add another variable, namely, urban development management. If Kazakhstan wants to modernise its cities to stimulate economic and social development, it should consider the tools and incentives to promote sustainable and comprehensive urban management.

\section{Urbanisation and Urban Management: Theoretical Aspects}

Urbanisation has affected every country in the world, and it continues to do so. It is characterised, firstly, by the rapid growth of urban population and, secondly, by the accelerated growth of large cities [4, p. 52]. Urbanisation is determined by the growth of urban industries, the development of various cultural and political factors, the strengthening of the territorial division of labour, and the improvement of living conditions of the urban population. This phenomenon is characterised by the influx of rural residents into cities and the increase of people visiting large cities from rural areas and nearby small towns (to work, for cultural and social reasons, etc.). Urbanisation can be treated differently, but the objective process of universal urbanisation is relentless [5, p. 7].

Through the prism of evolution, globally, there is a growth of interest in the features, sequential models, factors and principles of the development of urban areas for numerous driving forces, such as accelerated population mobility, post-industrial education and the progressive concentration of people in cities.

To understand the essence and reasons for the concentration of populations and economic activities in cities, it is advisable to examine classical theoretical principles and concepts presented in the works of Hoover [6], Isard [7], Krugman [8], Glazychev [5], Lappo [9], and Tatarkin [2]. From the perspective of these researchers, the attractiveness of cities, including the largest ones, is generally connected with the occurrence and development of the phenomenon of agglomeration effects (agglomeration economy).

Mikhurinskaya and Martirosova [10] presented the genesis of theories of urban development and world urban agglomerations. In their research, they outline a systematisation of theories related to the development of cities and urban agglomerations based on periods of formation and development. Thus, as an example, they described various theories of urban development by periods:
- Mediaeval Times and the Renaissance (theories of ideal cities: Plato, Aristotle, Hippocrates and the Renaissance);

- the 1920-30s (theories of population movement, theories of planning the structure of cities, the concept of a linear city (Soria y Mata), Le Corbusier's concept of three human establishments, the utopian idea of the circular city of Gloeden, the concept of Kristaller, Ecumenopolis of Doxiadis, and theories based on architecture);

- the 1950-60s (the theory of population settlement, the concept of a new element of settlement, network settlement system, kinetic settlement system);

- modern concepts (eco-city, humanopolis, the concept of urban metabolism, the concept of technopolis, charter cities proposed by Romer, aquapolises and cosmopolitans) [10, p. 114-118].

It is quite typical that in cities and agglomerations urban functions tend to strengthen post-industrial sectors, leading to changes in urban lifestyles and living conditions and city management mechanisms. Therefore, it is necessary to study the processes currently occurring on urbanised territories.

Urbanised areas are characterised by a high population density, mass concentration of various facilities (residential, industrial, recreational, infrastructural, etc.), the speed of information exchange and communication processes, and the diversity of human activities (work, leisure, communication, education, social life, etc.). All of the above processes and activities exist in limited urban areas, spilling over into agglomerations and involving participants, information and resources.

Thus, urbanised territories or cities are determined by a complex multifunctional territorial structure. The transition to post-industrial sectors is not decreasing, but rather their attractiveness is increasing. In this context, the human factor, that is, human capital, acts as a main driving force for the development of the knowledge economy and, consequently, for the development of urbanised territories. It is rather difficult to give an exact definition of urbanised territories, as they differ in the convergence of three areas (social, environmental and economic), where people-oriented values set the pace [11].

A high degree of territorial concentration of populations is a factor in accelerating the socio-economic, scientific and technological progress of humankind. It happens due to the intensification of business activities, the stimulation and strengthening of scientific and technical cooperation, and the information exchange between people. 
Various studies aimed to determine the economic benefits of the effects of agglomeration. For example, Hoover [6] substantiated the role of urban agglomerations as a large labour and real estate market with a strong concentration of investments for the development of industrial sectors. In the late 1940s, he studied the phenomenon of urban concentration and observed that production costs decreased when various industrial sectors were based on the same principle as enterprises belonging to the same industry (urban concentration economy). The city provides economies of scale for all firms, supplying necessary infrastructure (transport, communications, support, and service companies).

The assumption that firms and workers are more productive in large cities has also been discussed by Marshall [12], Jacobs [13], Henderson [14], Animitsa [15, 16], Kolomak [4], Zubarevich [17, 18], Rusanovsky and Markov [19] among others.

Jacobs [13] argued that cities act as active agents of economic growth and revealed a causal relationship linking economic growth with urbanisation. The economic development of a city largely depends on its local resources as well as industrial activities a city is involved in, including human resources, capital and raw materials. The effect of urbanisation explains the population growth in municipalities (an increase in the number and density of the population), as well as a stronger concentration of economic activities in certain areas, which ultimately strengthens the economy of a municipality (city).

According to Animitsa [15, p. 232], there is a link between the creation and rapid development of urban territories and modern development of society, characterised by increasing heterogeneity of the economic space and enhanced specialisation of certain parts in the performance of certain functions, and activated social and economic processes that have accelerated and compressed over time and space. As the researcher notes [16, p. 83], today the economies of many states are becoming typically urban.

\section{Urban management as a key approach in urban development}

Among developing nations, urban management has become commonplace, thanks in no small part to the introduction of the Urban Management Programme (UMP) in 1986. The UMP is a coordinated effort involving the World Bank, the UN Centre for Human Settlements (UNCHS) and the UN Development Programme (UNDP).

In terms of definitions, urban management has been described as a combination of instru- ments and activities that enables a city to function [20].

It allows fundamental services to be delivered to citizens, as well as empowers private and public stakeholders to contribute to society. If a city is to develop satisfactorily, urban management coordination relies on the efficiency and equity of resource distribution [21].

With so many actors involved, conflicts inevitably arise. Here, local governments must use their resources wisely and apply suitable tools to find relevant solutions that can harness the city's potential and enable sustainable and equitable development.

Van Dijk [22] claimed that a central component of urban management is the involvement of public and private sector to resolve a city's main issues.

Davey [23] asserted that urban management, if conducted competently, should ensure that infrastructure, housing and employment expand in line with population growth. In this process, public sector policies and private sector initiatives are equally vital.

Cities, relying solely on the public sector in the process of urban management, have encountered various problems. Accordingly, public-private partnership (PPP) has gained popularity in urban management as the private sector compensates for reduction in public funding and improves the efficiency [21, p. 7]. Thus, the privatisation of various parts of a city's infrastructure (e.g. public transport) is common.

However, local governments must be careful to delegate such important functions to only capable firms/agencies. Their lack of competence regarding resources and implementation would ultimately lead to insufficient urban management.

Furthermore, the relationships between local governments and state/provincial governments and community organisations are pivotal to the success or failure of urban management. They have become especially significant in countries with centralised administrations, such as some post-Soviet states.

While nations differ in terms of legislation and politics, there is a worldwide trend toward putting administrative, political and financial duties in the hands of local governments. In doing so, central governments take a step back, and essentially allow cities to make their own decisions to some extent, benefitting from a better understanding of local intricacies.

A key hurdle for urban management is the adequate provision of social and physical infrastructure. For that purpose, the attraction of sufficient investment is vital [24]. 
Traditionally, urban management has followed a supply-driven approach, when state and appointed agencies take responsibility for a city's development. Naturally, taxpayers expect their cities to provide and maintain services of an acceptable quality.

However, more recently, the approach to urban management has embraced civil society more, thus widening the number of stakeholders, encompassing nongovernmental organisation (NGOs), community based organisations (CBOs) and other [24, p. 37].

From a governance point, urban management requires an open outlook with decreased bureaucracy and increased transparency [24, p. 38].

Various factors can affect urban management, but few more so than globalisation, which has made major cities reinforce their positions as key locations for exchange and interaction. In this regard, the "regimes of accumulation" thesis points to the influence of massive shifts in labour and consumption trends, in particular, market deregulation.

Both domestically and internationally, decentralisation has become prominent [24]. Following the Cold War, state intervention dissipated in the markets, with local governments being strengthened instead.

Generally, the understanding of urban management has altered significantly over the years, particularly in the developing world. Government bodies have turned into service providers as once inflexible administrations become increasingly transparent and efficient. Now, citizens see themselves as customers who have a right to services of a certain standard. In turn, policy-makers and government departments now follow the standards set in business with respect to management.

In the developing world, cities are following suit, embracing information technologies to make their operations more transparent and effective. Notable leaders in this regard are Singapore and the Indonesian city of Sragen, both of which are setting an example for many developing cities.

Today, urban management techniques play a more noticeable role in the spheres of civil infrastructure and even real estate. One such technique is an agreement on staff objectives, through which public bodies and private firms share the burden in terms of resources and workload [25].

There is a consensus that civic governance entails focussing on services. The mantra of 'local government for citizens' involves the public actively assisting in designing and establishing public services. Across several cities, this approach has been highly effective with citizens engaged in the improvement and operation of all sorts of facilities [25].

For activities intended to modernise city governments, a results-oriented approach is essential for mutual benefit. In the process, it is imperative that the authorities open up to civil society, and involve various actors in their work.

There are three main conclusions from this section. First, the primary goal of urban management is to improve a city's competitiveness and sustainability. Second, urban management requires an integrated approach: as various sectors are involved in developing a city, all of them need to work in a synchronised manner. Third, urban management requires strategic and operational interventions. There must be a serious commitment on the part of the relevant government to ensure the private sector engagement [26]. Therefore, governments should also ensure that the playing field is level for all actors playing their part in urban management.

\section{Data and Methods}

The methodological basis of the paper is works of domestic and international scientists, as well as a set of legislative, regulatory acts, programme documents and decisions of the Government of the Republic of Kazakhstan, and official statistics of the Committee on Statistics of the Ministry of Finance of the National Economy of the Republic of Kazakhstan. To process the initial data, we used the methods of economic-statistical (statistical), monographic, system analysis.

\section{Results: Urbanisation processes in the post-Soviet republics}

Urbanisation in the post-Soviet republics, including Kazakhstan, first appeared in the era of the USSR, when industrial factors influenced the formation of cities [16, p. 88]. In the USSR, there was a system of territorial planning, built on the principles of economic zoning. Cities were closely integrated into production chains throughout the country, and not into the local economy [27, p. 107].

Due to the processes of economic disintegration and the reduction of production chains, many of these cities became uncompetitive by the mid1990s [28]. In the 1990s-2000s, there was a decrease in the urban population in the post-Soviet republics, which was observed throughout this entire period in Ukraine, Armenia, Kazakhstan, Moldova, and Russia until the middle of the first decade of the 21st century. This trend continued in Azerbaijan, Belarus, Kyrgyzstan, Turkmenistan and Uzbekistan, but in the early 2000s, its intensity was the lowest. Positive rates of urbanisation 
persisted only in Belarus and Ukraine. At the beginning of the new century, in most post-Soviet republics, the share of the urban population began to gradually increase, however, in general, the speed is lower than in the 1970s-1980s. Thus, in the past two decades, the pace of urbanisation in the post-Soviet republics has slowed.

The development of urbanisation processes in the history of Russia consists of several stages: the 19th-20th centuries; the Soviet era of the 20th century; and the modern period (from the 1990s to now) [29]. The Russian Federation essentially went through a phase of intensive urban development, since most Russian cities were formed back in the 1970s. Pivovarov [30, p. 102] notes that the rapid growth of the urban population is one of the main results of the development of urbanisation in Russia in the 20th century. The urban revolution led to a more than tenfold increase in the number of citizens residing in urban centres. The present is characterised by the qualitative development of cities and urban agglomerations. Russia can be attributed to countries with a high level of urbanisation, where almost half of the population lives in urban agglomerations [4, p. 60].

According to the data of the United Nations Economic and Social Commission for Asia and the Pacific (UN ESCAP), the countries of Central Asia have a model of urbanisation, where the population and economic activities are concentrated in large and very large cities. Moreover, small and medium-sized cities, despite their population and social value play a very insignificant role in the economic development of the countries in this region.

Urbanisation in general and the formation of megacities in particular are relatively new phenomena for Central Asia [31]. According to the 1989 All-Union Population Census, at the time of the collapse of the Soviet Union, the share of the urban population in the Central Asian republics ranged from 33 \% (Tajik SSR) to 57 \% (Kazakh SSR) and was noticeably lower than the average for the Soviet Union (66 \%). There were only two cities in the region with a population over one million: the largest regional centre, Tashkent and Alma-Ata, whose population was above one million only in 1981. Modern processes of urbanisation in Central Asia are uneven. The population of large cities, in which a significant part of the population of Central Asia lives, is growing rapidly. In the medium term, the population of large cities in Central Asia will continue to grow.

All the countries of Central Asia, except Kazakhstan, where three large cities are being formed, are facing a shortage of alternative growth centres. Therefore, each has only one "capital city", a metropolis where migrants from other regions gather.

As for Tajikistan, medium-sized cities have a deformed functional structure dominated by single-industry and highly specialised centres. The country's urbanisation policy is aimed at the parallel development of villages, as well as small, medium and large cities, along with the transformation of rural settlements into urban settlements and the stimulation of small, local production enterprises.

In Kyrgyzstan, in the context of an ever-increasing burden on Bishkek, where $25 \%$ of the country's population lives, several small cities are isolated from the main centres of socio-economic activity. The natural conditions and ecological environment of the Kyrgyz Republic dictate the need for the development of small and medium-sized cities, which can become a supporting element of the country's economic development.

In general, the lack of a comprehensive urbanisation policy in Central Asian countries increases the risk of false urbanisation. The growth rate of the urban population exceeds the rate of job creation, which leads to megapolisation, a phenomenon that results in an abnormal load on urban infrastructure, increased unemployment and worsening living conditions in cities.

The trends of urbanisation and deurbanisation, which are interconnected stages of any social environment, are among the fundamental laws affecting the vital activities of the respective territory, in both Kazakhstan and other former Soviet republics. Some cities grow, while others regress and eventually disappear; and these processes never stop. Let us take the example of single-industry towns that developed around manufacturing enterprises. As soon as their external supply runs dry or an economic crisis breaks out, such cities, especially small ones, lose their attractiveness and inhabitants, gradually turning into post-industrial deserts. A similar situation is observed in developed countries, as evidenced by cities such as Liverpool (United Kingdom), Detroit (United States of America), etc.

Simultaneously, globally speaking, urbanisation trends and agglomeration processes are quite intense, affecting the development of entire megacities, for example, in countries such as the USA, China, Japan, India and European countries.

In the post-Soviet space, cities with a simple export-oriented production chain are economically viable. For example, in the areas of oil and gas production in Azerbaijan, Kazakhstan, the Russian Federation and Turkmenistan, it is possi- 
ble to observe the growth of existing cities and the creation of new towns.

There is a noticeable increase in the concentration of the urban population in the capitals of post-Soviet countries, namely, Minsk (Belarus), Chisinau (the Republic of Moldova), Moscow (the Russian Federation), Kiev (Ukraine), and NurSultan (Kazakhstan).

All non-capital cities in the post-Soviet republics have a population of less than one million people, with the exception of some cities found in the Russian Federation, Ukraine and Kazakhstan. In Ukraine, the population of its 'other' cities is declining, which further ensures the dominance of its capital Kiev. However, in the Russian Federation, population growth in cities with a population of more than one million people has been recorded since the mid-2000s, mainly due to a positive migration balance [32]. The development of Ukraine's agglomerations indicates significant differences between its large cities and their population clusters (for example, modern agglomeration is characterised by a division between a privileged centre and peripheral zones, which lag behind in terms of social development). Agglomeration cannot be considered a useful management tool, since it is managed by various authorities. In addition, such territorial entities do not have any legal status. The development of such agglomerations has taken place in most post-Soviet states. In Kazakhstan, for instance, the agglomeration of its capital city Nur-Sultan includes parts of Akkol, Arshaly, Tselinograd and Shortandy districts of the Akmola region. In other words, the local authority body (akimat) of the city of Nur-Sultan is not a holistic management body, since the aforementioned districts are governed by the respective akimats of the Akmola region. Another example is the zone of influence of the city of Almaty, which was determined based on the nearest ties of the city with its suburbs, taking into account the location of its historically formed satellite cities, namely, Kapshagay, Kaskelen, Talgar, Esik and the village of Uzynagash. The same settlement tendency is characteristic of two other agglomerations, specifically, Shymkent and Aktobe. Thus, all risks should be considered, when it comes to the long-term planning of population growth in cities by providing adequate resources to citizens, creating affordable, high-quality infrastructure in metropolitan areas and developing programmes to help people migrating from rural areas adapt to the urban environment instead of doing so after the fact.

\section{Actual Development Trends of Cities in Kazakhstan}

It is possible to distinguish two stages of development of cities in Kazakhstan over the past two decades. The first saw the development of its large cities, namely, Nur-Sultan, Almaty and Shymkent. The concentration of the population in Kazakhstan increased in these three megacities. The population of these cities is growing faster than in other urban areas of Kazakhstan. From 2009 to 2014, the population of major municipalities in these three urban areas grew by $3.2 \%$ annually. This value is much higher compared to the country's medium-sized cities (1.6\%) or small urban areas (1.8\%). The spectacular growth of NurSultan coincided with the fact that the city became the centre of the administrative structure of Kazakhstan and the headquarters of many large state enterprises.

The second stage included the creation of a "highway" of national and regional cities where economic activity is concentrated. In addition to the development of three megacities, the government has focused on urban agglomeration, single-industry settlements and small towns.

Across Kazakhstan, the process of urbanisation is not uniform. Moreover, urban population growth in Kazakhstan is mainly due to internal migration. The migration of rural residents to cities is often due to the lack of permanent work in rural areas and poor social infrastructure.

Currently, the following cities in Kazakhstan have a high level of urbanisation: Nur-Sultan, Almaty, Shymkent, Aktobe, Karaganda and Pavlodar. The urban population in these cities is much higher than the national average; the contrast between urban populations by cities is shown in Figure 3.

The available data suggest the existence of correlations between the level of urbanisation in a region and the level of economic growth (the income of its population). The exception is the oil producing regions of Atyrau and Mangistau (Figure 4).

Figure 4 shows that in the highly urbanised regions of Nur-Sultan, Almaty, Aktobe, Pavlodar and Ust-Kamenogorsk (East Kazakhstan), population income is higher than in other regions. The diagram below shows that the largest number of enterprises with innovations is located in large cities (Figure 5).

In Kazakhstan, agglomerations are only just beginning to take shape around its largest cities, including Almaty, Nur-Sultan, Shymkent and Aktobe. At the end of 2018, the share of gross regional product in the country's GDP (61819.5 billion tenge) in the cities of Nur-Sultan (6706.0 bil- 


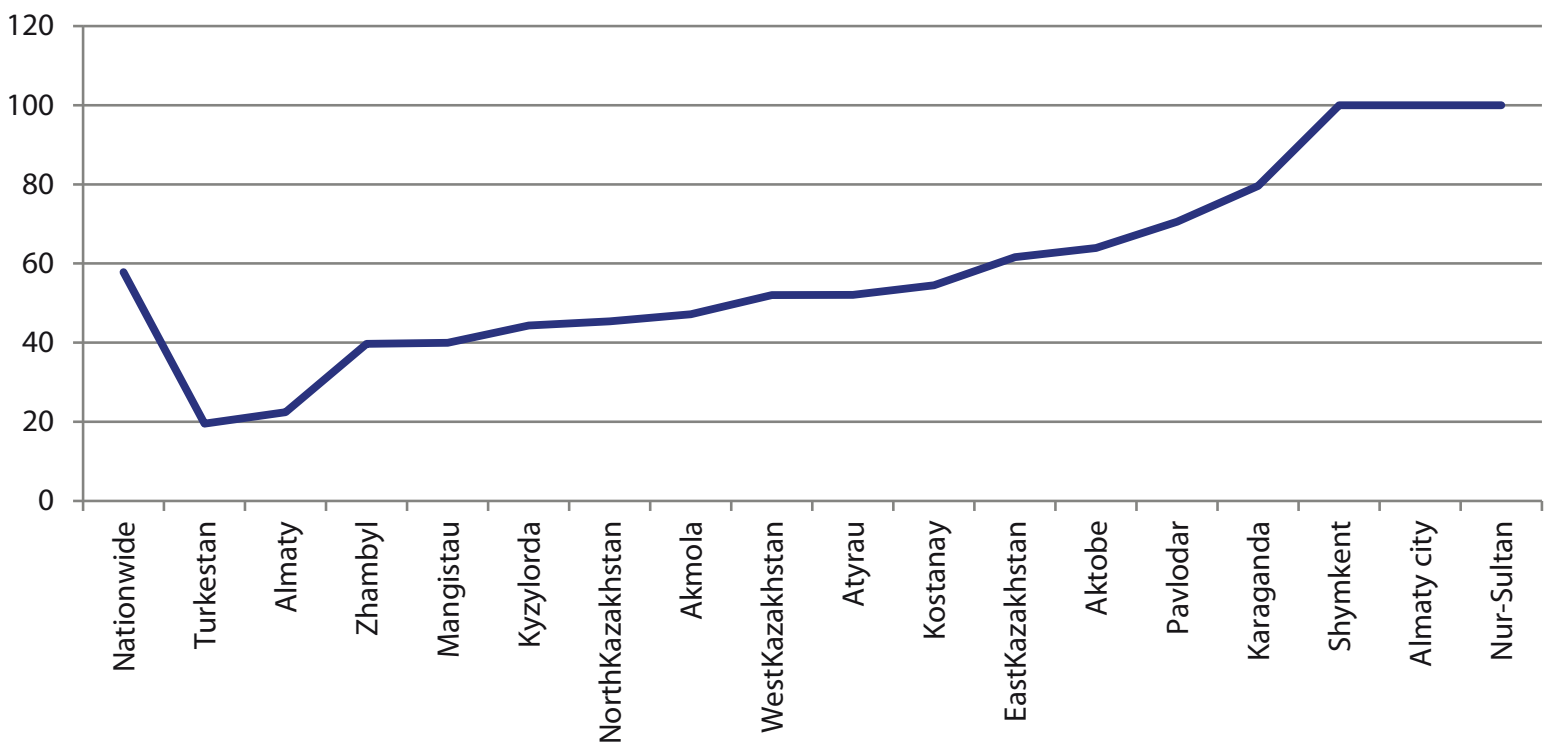

Fig. 3. Level of urbanisation of Kazakhstan regions (01.01.2019), \%

Source: compiled according to the Committee on Statistics of the Republic of Kazakhstan (Statistical Resources, Population) Retrieved from: http://stat.gov.kz/faces/wcnav_externalld/homeNumbersPopulation?_adf.ctrl-state=i9pbgecq7_60\&_afrLoop=1303226999836972 (Date of access: 10.10.2019)).

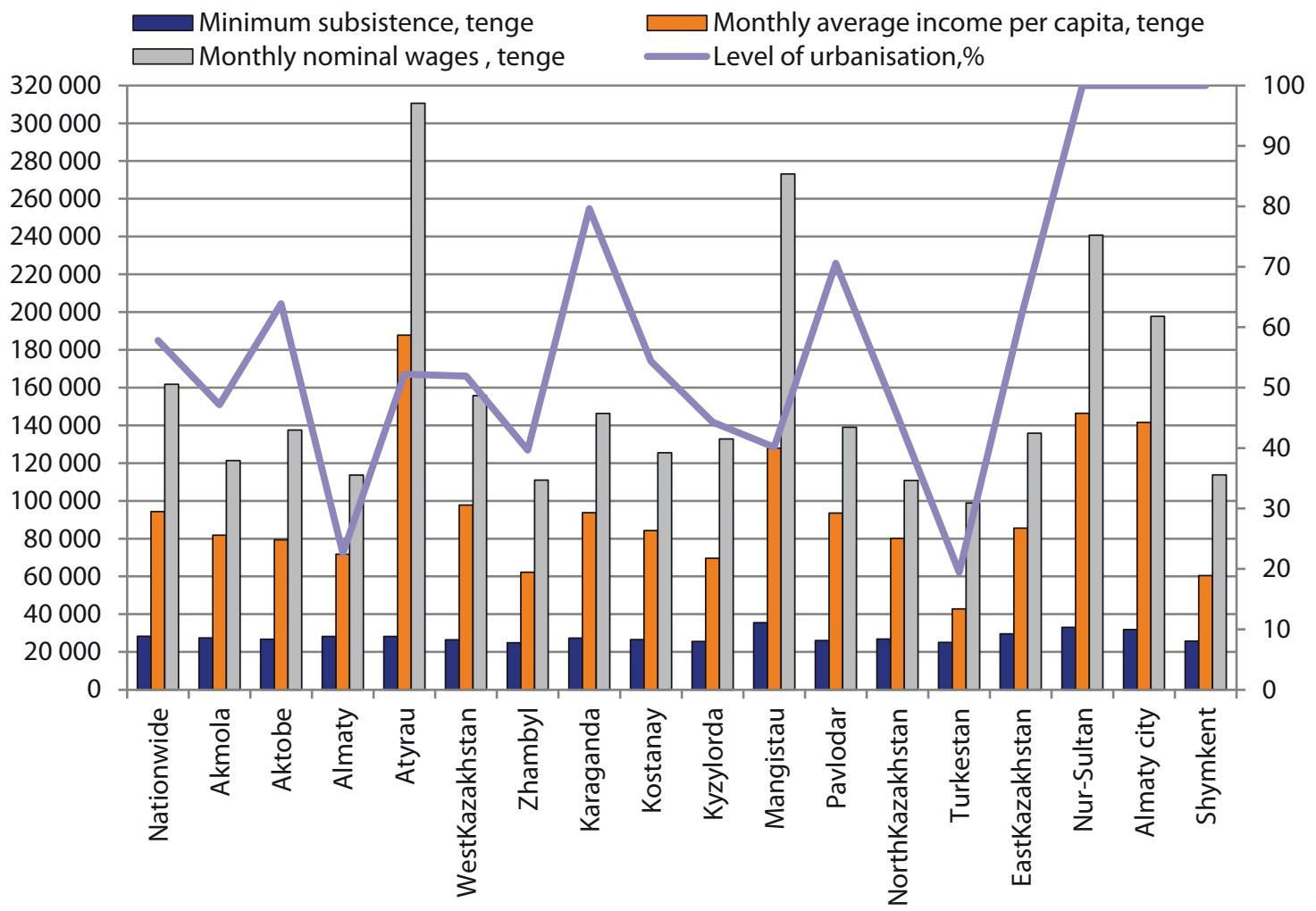

Fig. 4. Relationship between the level of urbanisation in a region and the level of income of its population (01.01.2019), \% Source: compiled according to the Committee on Statistics of the Republic of Kazakhstan (Statistical Resources, Population. Retrieved from: $h$ ttp://stat.gov.kz/faces/wcnav_externalld/homeNumbersLivingStandart?_afrLoop=2401108020646426\#\% 4 0\%3F_afrLoop\%3D2401108020646426\%26_adf.ctrl-state\%3Dxt6h8jg47_26 (Date of access: 10.10.2019)).Fig. 4. Relationship between the level of urbanisation in a region and the level of income of its population (01.01.2019), \% Source: compiled according to the Committee on Statistics of the Republic of Kazakhstan (Statistical Resources, Population. Retrieved from: http://stat.gov.kz/faces/wcnav_externalld/homeNumbersLivingStandart?_afrLoop=2401108020646426\#\%40\%3F_afrLoop\%3D2401108020646426\%26_adf.ctrl-state\%3Dxt6h8jg47_26 (Date of access: 10.10.2019)). 


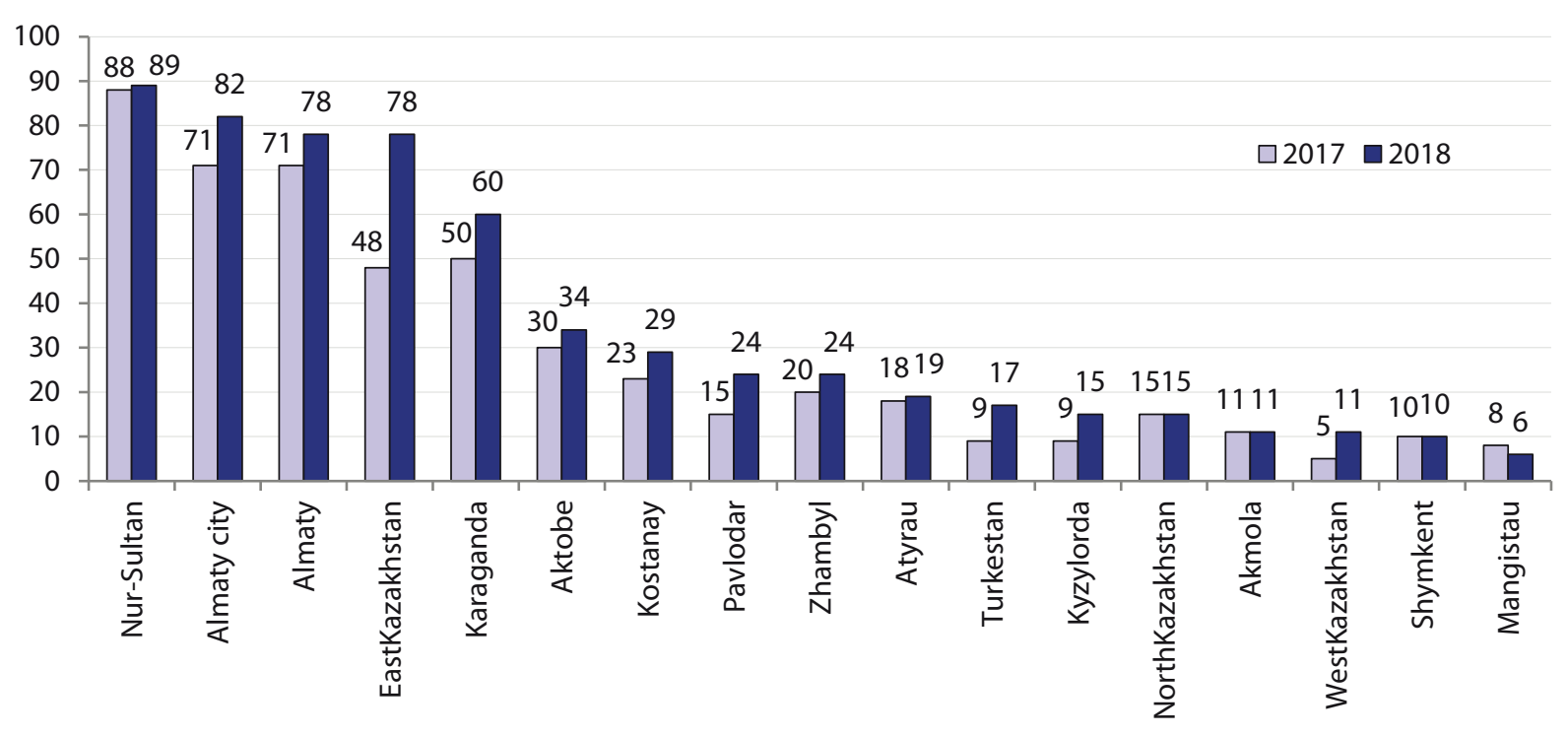

Fig. 5. Relationship between the level of urbanisation in a region and the number of enterprises with innovations (01.01.2019) Source: compiled according to the Committee on Statistics of the Republic of Kazakhstan (Statistical Resources, Population. Retrieved from: http://stat.gov.kz/ (Date of access: 10.10.2019). Migration balance (01.01.2019), thousand people. Source: compiled according to the Committee on Statistics of the Republic of Kazakhstan (Statistical Resources, Population). Retrieved from: http://stat.gov.kz/ (Date of access: 10.10.2019)).

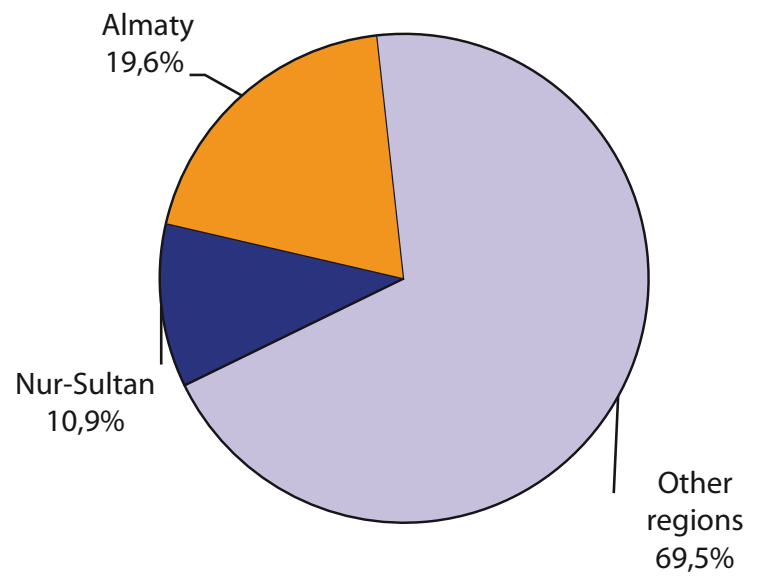

Fig. 6. Share of gross regional product (GRP) in the republican gross national product (GNP) (1.01.2019), \%

Source: compiled according to the Committee on Statistics of the Republic of Kazakhstan (Statistical Resources, Population). Retrieved from: http://stat.gov.kz/ (Date of access: 10.10.2019).

lion tenge) and Almaty (12132.6 billion tenge) amounted to $10.9 \%$ and $19.6 \%$, respectively (Figure 6).

Generally, Kazakhstan's big city agglomerations are at the initial stage in terms of urban development. The largest agglomerations are characterised by an unbalanced development in their central and suburban areas.

Given the main trends in the formation of urban agglomerations in modern Kazakhstan, it is possible to classify them based on heterogeneity of urban entities. The southern zone (mainly consisting of Shymkent, and to a lesser extent Almaty, Kyzylorda and Zhambyl regions) is characterised by an expanded reproduction of the population, which is the main source of its growth. Moreover, its growth rate, even taking into account the migration outflow, quite clearly corresponds to the scale of urban development in developing countries. The dynamics of modern development are characteristic of the largest agglomeration in the country (Almaty), which is gradually restoring the growth rate corresponding to the stage of urbanisation of a large city. The mid-latitude zone of Kazakhstan differs the most in terms of urban development. The country's rapidly growing capital, Nur-Sultan, as well as Karaganda are developing as new growth centres. The main advantage of the resettlement zone of Karaganda in the future will be the existing territorial structure, which will become the basis for further spatial development. The northern belt of agglomerations (uniting agglomerations of all regions bordering Russia, typologically including East Kazakhstan) is represented by typical monocentric, intra-regional agglomerations. So far, the formation of urban agglomerations in the country's northern belt is unlikely, although it is in this very settlement zone that the natural, economic and infrastructural prerequisites for such development are most favourable.

Considering the problem of agglomeration development in Kazakhstan, it is possible to formulate criteria for determining the circle of urban centres with a positive potential for agglomeration development: geographical location, administrative status, status of the country's capital, socio-demographic situation, and population density. 


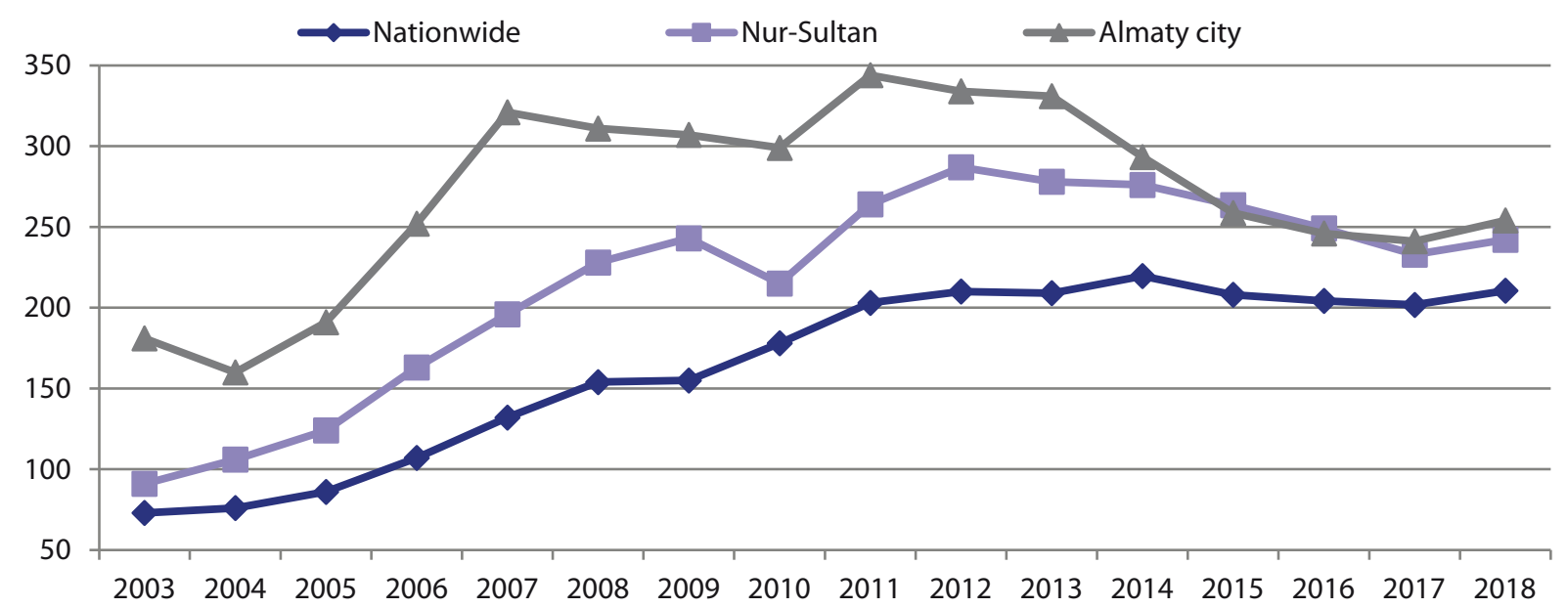

Fig. 7. Proportion of the population with passenger cars, units per 1000 residents (2003-2018) Source: compiled according to the Committee on Statistics of the Republic of Kazakhstan (Statistical Resources, Population). Retrieved from: http://stat.gov.kz/faces/publicationsPage/publicationsOper/homeNumbersTransport?_afrLoop $=2075730030153894 \# 40 \% 3 F \_a f r L o o p \% 3 D 2075730030153894 \% 26$ adf.ctrl-state\%3Delqoo9q27_4 (Date of access: 10.10.2019)).

The socio-demographic situation has a significant impact on the development of agglomeration processes. Based on international experience and the country's characteristics, it can be assumed that, in Kazakhstan, an agglomeration effect occurs only in cities with a population of more than 0.5 million people (or in a group of interconnected neighbouring cities).

The area around the city plays the role of the main supplier of human resources. The rapid growth due to market factors can be expected in cities with a higher population density and relatively developed transport infrastructure, which is typical only for the south of Kazakhstan (Almaty, Shymkent). Cities without dense settlements around them have limited growth resources, which is the case for the majority of Kazakh regions.

The service sector is very important for agglomerations; therefore, the economic structure of Almaty in particular has great agglomeration potential. In addition, significant human resources are available in the large industrial cities of Kazakhstan (Karaganda, Pavlodar and Ust-Kamenogorsk), which have the status of administrative centres of the regions. Thus, the development of a service economy is also expected there.

The most important factor in the development of urban agglomeration is the state of its infrastructure. The analysis of the current state of infrastructure of the considered agglomerations showed their unpreparedness for the load, which occurred as a result of their rapid growth. For example, when analysing the infrastructure of the cities of Almaty and Nur-Sultan, we see that passenger cars dominate public transport. Initially, after independence, relatively few people owned cars, and there was a developed, albeit imperfect, urban public transport system. However, over time, the number of cars has grown, especially in the two aforementioned cities (Figure 7).

The public transport system inherited by Kazakhstan is inadequate. As the most popular form of public transport is the bus, traffic congestion is a major drawback. Strategies are being developed in Nur-Sultan and Almaty to introduce high-speed trains, albeit in the long term. It is difficult to establish affordable and sustainable public transport for the cities of Kazakhstan. One particular issue is the lack of a strategic long-term approach. To address this issue, authorities should clearly indicate the role of cities in transport and housing planning and then expand their technical capabilities accordingly. Authorities must ensure the integration of urban planning, transportation and other urban conditions, choosing an approach based on a network and strategy. The low level of infrastructure development is the most important factor limiting the socio-economic growth of the adjacent territories of the Nur-Sultan agglomeration. Of particular significance are the unsatisfactory technical conditions of regional, district and intra-district roads. More than $50 \%$ of local roads with asphalt and gravel pavement have defects and require repairs. For example, a significant threat to the development of the Nur-Sultan agglomeration is the absence of long-term, city development plans. Clearly, the most fundamental factor in the development of a city is large-scale public investment. An analysis of the structure of Nur-Sultan's economy indicates a large share of public services and a strong dependence on industries related to 
investment activities (construction and the building materials industry), whose dynamics will decrease in the future.

The economic growth of Nur-Sultan and, as a result, the intense population dynamics have led to an increasing load on the life-supporting infrastructure of the city (transport, engineering, electric networks).

For example, in Kazakhstan, while Nur-Sultan leads in terms of population growth, it is not accompanied by adequate provision and construction of social infrastructure facilities. In general, the continuing influx of migrants and insufficient employment opportunities can become a negative factor in the development of an agglomeration. Although the city has suitable territory and housing, the high cost of living in the capital is the main obstacle to the social adaptation of migrants. In addition, there are a number of problems in providing the population with social services, and, so far, the economic potential for the deployment of social programmes is low.

\section{Discussion and Implications}

Although cities face serious challenges, from poverty to pollution, they are also centres of economic growth and innovation.

The future of cities largely depends on how we plan and manage urbanisation, and whether we can use the transformation of this process to provide the foundation and momentum for global change. A strategic vision, proper planning and financing of cities will help provide a solution to many problems.

We have identified the need for effective management of urban areas. For instance, analysis of the international experience in the management of urbanised territories allows distinguishing two main forms of management: centralised and decentralised [15, p. 234; 33]. In centralised management, all management decisions related to the creation, functioning and development of urban education are made by the main governing body. The decentralised form is characterised by a horizontal (not vertical) distribution of management functions between the municipalities of agglomeration. Existing management models, in turn, are divided into single-level and two-level. The single-level model is based on a single management level for all urban entities, one variety of which is a contractual model (fragmented) based on the use of mechanisms of inter-territorial cooperation. The two-level management model involves creating a permanent supra-territorial government whose powers include issues important for urban centres and urban agglomeration.
In Kazakhstan, it is necessary to consider both decentralised and centralised forms of agglomeration management [34]. At the state level, strategic programmes, concepts and other documents on agglomeration management are being formed. At the local level, an effective decentralised management system is needed to take into account the interests of cities at all levels, rural settlements, local government institutions [35].

The analysis of existing urban agglomeration management models showed that excessive fragmentation of the agglomeration management system entails the risk of losing control over its socio-economic development, or in other words, the urban agglomeration losing a sense of subjectivity. In its turn, it entails the asynchronisation of socio-economic processes within the agglomeration and slows down the development. As a result, it is necessary to create a holistic management approach to urban agglomeration in Kazakhstan based on a two-level management model.

Today, while there are development programmes in every region across Kazakhstan, as well as in the cities of Nur-Sultan and Almaty, their effective implementation has raised doubts. The analysis of the development programmes of the cities of Nur-Sultan, Almaty, Shymkent and Aktobe shows that only the first two see sustainable development as the main goal of the territory's development. The main task of local authorities is to solve pressing problems of the population. Often, there is a misunderstanding of the importance of strategic planning by both local authorities and the local community. Modern realities require considering constantly changing economic conditions, confronting competition in all kinds of markets and attracting investment resources. It is necessary to develop a holistic approach for the management of urbanised territories that would allow formulating directions, principles and strategies for the development of cities and territories. Consequently, the active use of management mechanisms and various agglomeration development models is ultimately designed to provide improved management of urban centres across the entire country.

Experience in the development of agglomerations shows that the most effective management models are those that provide sufficient flexibility in decision making, taking into account the interests of various territorial communities and the rights of territorial units. An agglomeration should be considered a single socio-economic, investment space with a common economy, as well as social, transport and engineering services, and an environmental base. All these aspects in- 
volve the elaboration and coordination of development plans for the entire territory of the agglomeration. The lack of an agreed agglomeration development strategy can lead to serious negative consequences, which may require a significant amount of resources to overcome. The strategy of socio-economic development of the agglomeration should determine its main goals, the key areas of economic development, and the social sphere of the planned territory for the long term (15-20 years). The government should consider urban agglomeration as a single urban unit when making management decisions. All agglomeration centres, in particular the cities of Almaty and NurSultan, face the problem of limiting the growth of their population along with the transition to new principles of development for creating a favourable living environment. All strategic documents of the country related to its spatial development focus on development in terms of controlled urbanisation. This factor determines the need to pay special attention to managing the dynamics of socio-demographic processes in the rapidly growing cities of Kazakhstan. A decrease in attention to agglomeration processes leads to the phenomenon of false urbanisation and increases social disharmony in cities. Overcrowding in agglomeration centres (particularly in cities such as Almaty, NurSultan and Shymkent), especially without adequate urban infrastructure, accompanied by a lack of employment areas can lead to the development of a negative scenario regarding processes related to agglomeration in Kazakhstan.

Therefore, it seems necessary to switch to principles of sustainable spatial development: the growth of cities instead of their territorial expansion, the separation of functions and areas of specialisation between the city centre and its environs that will become independent centres of economic employment, the transformation of agglomerations into cities of regional scale, etc.

A new approach is also required for planning urban development, considering metropolitan areas as special interconnected entities. Such an approach would ensure the comprehensiveness and harmony of the socio-economic development of the city and its agglomeration environment. Based on the analysis, we identified problematic aspects of the development of urban centres in Kazakhstan, which should be taken into account:

- The cores of metropolitan areas pull productive forces from suburban areas;

- Lack of demographic resources for the formation of agglomeration centres of the second and third levels restrain the economic development of the country's regions.
- Urban infrastructure is unable to cope with the massive influx of migrants.

- The formation of a wide layer of marginalised, unemployed urban population is a source of crime and social instability.

- The development of an agglomeration is associated with the exhaustion of a city's capability to accommodate production, infrastructure facilities, etc., as well as the need for its development on a wider territorial basis.

- The existence of complex traffic problems.

- Environmental pollution.

These problematic aspects should be considered comprehensively, taking into account the prospects for the development of adjacent territories in the format of an agglomeration.

To solve all these problems, it is necessary to change management approaches. As all settlements included in the agglomeration must be developed, it is important to actively use the agglomeration effects in the management of urban agglomerations to ensure effective development of urban agglomerations.

\section{Conclusions}

The experience of Kazakhstan, as outlined in detail above, indicates that the development of cities as well as economic growth in general rely heavily on competent urban management. Economic, social and environmental aspects of sustainable development affect urban growth, known sometimes as urbanisation. Suitable control of urbanisation and monitoring and implementation of population trends would allow urban residents to improve their lives without causing great environmental harm despite pessimistic forecasts. The universal accessibility of infrastructure and social services can help urbanisation benefit more people.

In terms of urban development, the cities of Kazakhstan will have to undergo significant changes to attract more domestic and foreign investment. Investors' decisions as to where to put their money are often based on the level of urban, technological and industrial infrastructure of the territory. Of course, strategies for urban areas must abide by current best practices, including, among other things, the formation of science parks and special development and/or trade zones. Ultimately, Kazakhstan's approach to urban development and policy needs to become more strategic.

The Kazakh government should pay special attention to urban development. In the country, there is no unified urban development vision to integrate economic, social, environmental and 
physical development strategies. To address this flaw, the drafting of a detailed strategic document may serve to outline the priorities of urbanisation, noting the vital role of cities in achieving sustainability. In addition, it must be borne in mind that urban development is founded on sectoral planning. Hence, insufficient coordination between central bodies dealing with urban development jeopardises the whole process, which is worsened further by administrative problems. Neither politicians nor the public have been paying sufficient attention to urban development and its related aspects.

If Kazakhstan is going to enact smart and effective regional and urban policies, it will be necessary to strengthen its multilevel governance. Its administrative structures remain old-fashioned and too centralised, lacking the flexibility needed to provide suitable policies for the country's diverse regions.
Both the central government and the local communities manage urban development policies and programmes. However, for the situation to improve, it is essential to involve subnational actors, and conduct regular policy and programme evaluations to ensure their continuous development.

Cities are centre stage, when it comes to territorial development strategies. However, in many countries, urban policies are reactive rather than proactive; they respond to problems rather than prevent them. This approach is not dynamic or even cost-effective. Today, urban issues are a priority for developing new strategies at the national, regional and local levels. Authorities at every level of government need to review and amend their functions and responsibilities, and seek solutions that will allow them to achieve a tangible synergistic effect through appropriate interactions and mechanisms.

\section{References}

1. Kulkki, S. (2014). Cities for Solving Societal Challenges: Towards Human-centric Socio-economic Development? Interdisciplinary Studies Journal, 3(4), 8-14.

2. Tatarkin, A. I. (2012). Development of the economic space of Russia's regions on the basis of cluster principles. Ekonomicheskie i sotsialnyye peremeny: fakty, tendentsii, prognoz [Economic and social changes: facts, trends, forecast], 3(21), 28-36. (In Russ.)

3. Florida, R., Adler, P. \& Mellander, C. (2017). The city as innovation machine. Regional Studies, 51(1), 86-96. DOI: $10.1080 / 00343404.2016 .1255324$.

4. Kolomak, E. A. (2011). Assessing how urbanisation influence an economic growth in Russia. Region: Ekonomika $i$ Sotsiologiya [Region: Economics and Sociology], 4, 51-69. (In Russ.)

5. Glazychev, V. L. (2011). Gorod bez granits [City without borders]. Moscow: Territory of the Future, 400. (In Russ.)

6. Hoover, E. M. (1948). The location of economic activity. New York: McGraw-Hill, 208.

7. Isard, W. (1956). Location and Space - Economy. New York: John Wiley, 350.

8. Krugman, P. (2005). Space: the final frontier. Trans. from English. Prostranstvennaya ekonomika [Spatial Economics], 3, 121-136.

9. Lappo, G. M. Polyan, P. M. \& Selivanova, T. V. (2007). Agglomerations of Russia in the XXI century. Vestnik fonda regionalnogo razvitiya Irkutskoy oblasti, 1, 45-52. Retrieved from: http://www.frrio.ru/uploads_files/vestnik.pdf (Date of access: 01.09.2019). (In Russ.)

10. Mikhurinskaya, E. A. \& Martirosova, R. A. (2011). Urban agglomerations as a form of urbanized territories development. Ekonomika i upravlenie, 4, 114-118. (In Russ.)

11. Khusnutdinova, S. R. (2015). The urban areas as an object of strategic planning and management. Sovremennye problem nauki i obrazovaniya [Modern problems of science and education], 2(2). Retrieved from: http://www.science-education.ru/pdf/2015/2-2/603.pdf (Date of access: 10.09.2019). (In Russ.)

12. Marshall, A. (1890). Principles of Economics. London: Macmillan.

13. Jacobs, J. (1969). The Economy of Cities. New York, NY: Random House, 268.

14. Henderson, V. (2010). Cities and Development. Journal of Regional Science, 50(1), 515-540. DOI: 10.1111/j.14679787.2009.00636.x.

15. Animitsa, E. G. (2012). Outlines of the theory of urban agglomerations' self-development. Ekonomika regiona [Economy of region], 1, 231-235. Retrieved from: http://economyofregion.com/archive/2012/39/1428/pdf/ (Date of access: 20.09.2019). Russ.)

16. Animitsa, E. G. (2013). Russian Megapolises and Global Urbanisation Processes. Ars Administrandi, 1, 82-96. (In

17. Zubarevitch, N. V. (2010). Cities as centers of modernization of economy and human capital. Obshchestvennye nauki i sovremennost [Social Sciences and Contemporary World], 5, 5-19. (In Russ.) Russ.)

18. Zubarevich, N. V. (2012). Social differentiation of Russian regions and cities. Pro et contra, 16(4-5), 135-152. (In 
19. Rusanovsky, V. A. \& Markov, V. A. (2015). Factor of urbanization in spatial models of their economic growth: estimate and peculiarities in Russian Federation. Vestnik Tambovskogo Gosudarstvennogo Universiteta. Seriya: Gumanitarnye nauki [Tambov University Review. Series: Humanities], 7(147), 113-124. (In Russ.)

20. Acioly, C. J. (2003). The Meaning and Scope of Urban Management: an introductory note. In: A. Sirry (Ed.), Urban Management Practices in Secondary Cities in Egypt: the case of Belbeis. New York: Macmillan

21. Bačlija, I. (2013). Reconceptualisation of urban management: evidence from EU cities. Theoretical and Empirical Researches in Urban Management, 8(1), 30-50.

22. Van Dijk, M. P. (2006). Urban Management Makes Cities More Competitive, But Requires Capacity Building. Urbanicity: City Matters.

23. Davey, K. J. (1993). Elements of Urban Management. World Bank: Urban Management Programme Discussion Paper.

24. Arefi, M. (2013). Towards a conceptual framework for urban management. City, Culture and Society, 4, 37-48. DOI: 10.1016/j.ccs.2012.11.010.

25. Pearce, D. G. (2015). Urban management, destination management and urban destination management: A comparative review with issues and examples from New Zealand. International Journal of Tourism Cities, 1(1), 1-17.

26. Wong, S. W., Tang, B. S. \& Van Horen, B. (2006). Strategic urban management in China: A case study of Guangzhou Development District. Habitat International, 30(3), 645-667.

27. Vlasova, N. Y. \& Antipin, I. A. (2010). Urban Agglomerations: History, Present State, Strategic Guidelines. Journal of new economy, 3(29), 106-112. (In Russ.)

28. Shcherbakova, E. (2013). Urbanisation slows in most CIS countries. Demoskop Weekly [Demoscope Weekly], 575576. ../../../././../../Downloads/Retrieved from: http:/www.demoscope.ru/weekly/2013/0575/barom02.php. Retrieved from: http://www.demoscope.ru/weekly/2013/0575/barom02.php (Date of access: 15.08.2019). (In Russ.)

29. Lappo, G. M., Polyan, P. M. \& Selivanova, T. V. (2010). Urban agglomerations of Russia. Demoskop Weekly [Demoscope Weekly], 407-408. Retrieved from: http://www.demoscope.ru/weekly/2010/0407/tema03.php (Date of access: 10.10.2019). (In Russ.)

30. Pivovarov, Yu. L. (2001). Urbanization of Russia in the 20th century: perceptions and reality. Obshchestvennye nauki i sovremennost [Social Sciences and Contemporary World], 6, 101-113. (In Russ.)

31. Dankov, A. (2016). Big Cities in Central Asia: Between Demography and Politics. Demoskop Weekly [Demoscope Weekly], 677-678. Retrieved from: http://www.demoscope.ru/weekly/2016/0677/analit04.php (Date of access: 20.09.2019). (In Russ.)

32. Rudenko, L. (2013). The main trends in the development of Ukrainian cities. In: L. Rudenko (Ed.), Izmeneniya Gorodskogo Prostranstva v Ukraine [Urban territories changes of Ukraine] (pp. 44-59). Kiev. (In Russ.)

33. Volchkova, I. V. \& Minaev, N. N. (2013). Models management of agglomerations: international experience and Russian practice. Ekonomicheskie nauki [Economic sciences], 11(108), 53-57. Retrieved from: http://ecsn.ru/files/ pdf/201311/201311_53.pdf (Date of access: 20.09.2019). (In Russ.)

34. Linn, J. (2014). Urbanization, Regional Development, and Decentralization. In: A. Aitzhanova, S. Katsu, J. F. Linn, V. Yezhov (Eds.), Kazakhstan 2050: Toward a Modern Society for All (pp. 187-221). Oxford: Oxford University Press.

35. Nellis, J. (2014). Institutions for a Modern Society. In: A. Aitzhanova, S. Katsu, J. F. Linn, V. Yezhov (Eds.), Kazakhstan 2050: Toward a Modern Society for All (pp. 285-310). Oxford: Oxford University Press.

\section{About the authors}

Svetlana O. Mukhametzhan — PhD student, Master of Global Political Economy, Master of Public Administration, Academy of Public Administration under the President of the Republic of Kazakhstan; https://orcid.org/0000-0003-04375048 (33A, Abay Ave., Nur-Sultan, 010000, Kazakhstan; e-mail: s.mukhametzhan@apa.kz).

Gulsara A. Junusbekova - PhD in Economics, Professor of the Institute of Management, Academy of Public Administration under the President of the Republic of Kazakhstan; Scopus Author ID: 55115763300; http://orcid.org/00000002-2709-652X (33a, Abay Ave., Nur-Sultan, 010000, Kazakhstan; e-mail: gulsara.dzhunusbekova@apa.kz).

Marat Ye. Daueshov - PhD in Economics, Deputy Chairman of Agency of the Republic of Kazakhstan for Civil Service Affairs (33a, Abay Ave., Nur-Sultan, 010000, Kazakhstan; e-mail: dmarat@mail.ru).

\section{Информация об авторах}

Мухаметжан Светлана Ораловна - докторант, магистр мировой политической экономии, магистр государственного управления, Академия государственного управления при Президенте Республики Казахстан; ORCID: https://orcid.org/0000-0003-0437-5048 (Казахстан, 010000, г. Нур-Султан, проспект Абая, д. 33a; е-таil: S.Mukhametzhan@apa.kz).

Джунусбекова Гульсара Аширбаевна - кандидат экономических наук, профессор Института управления, Академия государственного управления при Президенте Республики Казахстан; Scopus Author ID: 55115763300; ORCID: http://orcid.org/0000-0002-2709-652X (Казахстан, 010000, г. Нур-Султан, проспект Абая, д. 33а; е-таil: Gulsara.Dzhunusbekova@apa.kz). 
Дауешов Марат Еркинович - кандидат экономических наук, заместитель председателя Агентства Республики Казахстан по делам государственной службы (Казахстан, 010000, г. Нур-Султан, проспект Абая, д. 33a; е-таil: dmarat@mail.ru).

Дата поступления рукописи: 23.04.2019.

Прошла рецензирование: 04.06.2019.

Принято решение о публикации: 15.09.2020.

Received: 23 Apr 2019.

Reviewed: 04 Jun 2019.

Accepted: 15 Sep 2020. 